\title{
MEMBERDAYAKAN MASYARAKAT ISLAM MELALUI BANK SAMPAH: STRATEGI KOMUNIKASI STAKEHOLDER BANK SAMPAH SONGOLIKOER
}

\author{
Wahanani Mawasti \\ STID Al-Hadid, Surabaya \\ wahananimawasti@yahoo.co.id
}

\author{
Tri Djoyo Budiono \\ STID Al-Hadid, Surabaya \\ djoyobudi@gmail.com
}

\begin{abstract}
Abstrak: Pemberdayaan masyarakat Islam mutlak membutuhkan partisipasi dari berbagai stakeholder. Untuk membangun partisipasi dan dukungan dari berbagai stakeholder diperlukan strategi komunikasi stakeholder yang tepat. Sejauh ini studistudi bertemakan stakeholder dalam pemberdayaan masyarakat, lebih banyak mendeskripsikan peranan stakeholder dalam keberhasilan pemberdayaan masyarakat dan langkah mapping/pemetaan stakeholder. Namun, belum banyak menguraikan tentang strategi komunikasi yang relevan dalam membangun hubungan yang harmonis pada stakeholder-stakeholder dalam konteks pengembangan masyarakat Islam. Studi ini berorientasi memaparkan strategi komunikasi stakeholder dalam pemberdayaan masyarakat Islam pada fenomena pendirian Bank Sampah Songolikoer Surabaya. Penelitian ini menggunakan metode kualitatif-lapangan, melalui wawancara semi terstruktur dengan informan yang ditetapkan secara purposive. Hasil studi ini adalah strategi komunikasi stakeholder yang digunakan cenderung mengolaborasikan antara strategi komunikasi stakeholder jenis responsif dan asertif. Strategi tersebut cukup relevan dalam pendirian Bank Sampah mengingat karakteristiknya tidak memaksa, membuka dialog kepentingan di antara kedua belah pihak, ada penyesuaian kepentingankepentingan yang dilakukan oleh masing-masing stakeholder sehingga menciptakan hubungan harmonis, berkurangnya konflik-konflik dalam pelaksanaan kegiatan pengembangan masyarakat sekaligus tetap memastikan tercapainya tujuan komunikasi yang diharapkan.

Kata kunci: Strategi Komunikasi Stakeholder, Pemberdayaan Masyarakat Islam, Bank Sampah.
\end{abstract}

Developing Islamic Community Through Waste Bank: Communication Strategy to The Stakeholders of Bank Sampah Songolikoer. Abstract: Islamic community development inevitably needs participation from various stakeholders. In order to build participation and support from various stakeholders, a communication strategy needs to be determined appropriately. So far, the studies, related to the stakeholder in community development as a theme, have described more about the roles of stakeholders in succeeding community development and steps on stakeholder mapping. Those rarely explain about relevant communication strategies on building harmonious relationships to the stakeholders in the context of Islamic community development. This study aims to describe about a communication strategy for stakeholders in Islamic community development, especially related to the phenomenon of establishment of Bank Sampah Songolikoer - Surabaya. This research applies field-qualitative method, through semi-structured interview over selective sampling of informants. As a result, the types of communication strategies used tend to collaborate between responsive and assertive ones. Those strategies are relevant in establishing Waste Bank, considering that their characteristics are noncoercive, able to open a dialogue between two parties, and adjustable on various stakeholders' interests - so that they can create harmonious relationships, minimize 
conflicts in conducting community development activities, and ensuring the expected communication goals.

Keywords: Communication Strategy, Stakeholder, Islamic Community Development, Waste Bank

\section{Pendahuluan}

Tulisan ini membahas strategi komunikasi stakeholder sebagai bagian dari dakwah Islam. Khususnya dalam konteks dakwah bilhal dalam bentuk pemberdayaan masyarakat Islam melalui pendirian Bank Sampah. Hal ini dilatarbelakangi oleh pentingnya strategi komunikasi stakeholder dalam membangun partisipasi dan dukungan berbagai stakeholder dalam pemberdayaan masyarakat Islam. Kegiatan pemberdayaan masyarakat selalu membutuhkan kemitraan dengan berbagai stakeholder guna menjamin terjadinya pembangunan yang sinergis baik antara kekuatan politik, kekuatan ekonomi (sektor swasta) serta kekuatan moral dari masyarakat. ${ }^{1} \quad$ Adanya partisipasi dari berbagai stakeholder menjadikan pemberdayaan masyarakat lebih membumi, karena dapat mencerminkan dan menjawab kebutuhan nyata dari masyarakat. Tanpa keterlibatan/partisipasi dari berbagai stakeholder kegiatan pemberdayaan masyarakat Islam akan sulit dilaksanakan, dilanjutkan dan akan mengalami kegagalan. ${ }^{2}$ Namun, upaya mendorong partisipasi stakeholder dalam pemberdayaan masyarakat bukanlah hal yang mudah. Masing-masing stakeholder memiliki kepentingan yang hendak diperjuangkan sehingga tak jarang melahirkan konflik atau

\footnotetext{
${ }^{1}$ IW. Mudana, Sosiologi Antropologi Pembangunan, (Yogyakarta: Graha IImu, 2015), 41

2 Shinta Prastyanti, "Komunikasi, Partisipasi dan Konflik Dalam Kegiatan Pemberdayaan Masyarakat," Jurnal Acta Diurna, Vol. 14 No. 1 (April 2018), 73.
}

\begin{abstract}
ketidaksetujuan terhadap program pemberdayaan masyarakat. Untuk mengatasi hal tersebut dibutuhkan upaya/strategi komunikasi kepada para stakeholder agar tercipta mutual understanding di antara para stakeholder. ${ }^{3}$
\end{abstract}

Novek dalam Prastyanti mengungkapkan betapa pentingnya komunikasi dalam pemberdayaan masyarakat dan perubahan sosial. Salah satu peran tersebut adalah kemampuan komunikasi dalam menghubungkan simpul-simpul yang terputus (meliputi: perbedaan persepsi maupun kepentingan) selama proses pemberdayaan masyarakat sehingga konflik yang dimungkinkan terjadi dapat teratasi dan menciptakan hubungan harmonis di antara para stakeholder yang terlibat. Hubungan-hubungan yang terjalin melalui proses komunikasi tersebut dapat melahirkan kesamaan kebutuhan antar berbagai stakeholder. ${ }^{4}$

Membangun komunikasi pada stakeholder merupakan langkah awal yang penting, sebelum melaksanakan tahapan pemberdayaan masyarakat selanjutnya, seperti: tahap pengapasitasan pengorganisasian sumber daya maupun pelaksanaan kegiatan pemberdayaan masyarakat. Keberhasilan komunikasi

\footnotetext{
3 Ibid, 75.
}

4 Ibid, 74-75. 
stakeholders akan menjamin adanya pemahaman tujuan bersama antarpara stakeholder dan menghindarkan konflikkonflik antarpemangku kepentingan semenjak awal sebelum usaha pengapasitasan masyarakat dilaksanakan.

Tulisan ini mengulas tentang strategi komunikasi stakeholder dalam pemberdayaan masyarakat Islam, yang diterapkan dalam pendirian Bank Sampah Songolikoer. Bank Sampah Songolikoer merupakan komunitas yang lahir di tengah masyarakat menengah ke bawah di daerah Wonokusumo Kidul Surabaya. Selain adanya persoalan ekonomi, masyarakat di daerah ini juga memiliki persoalan terkait rendahnya kepedulian masyarakat terhadap lingkungan, khususnya kebersihan. Lokasinya yang berdekatan dengan TPS selain menciptakan kesan kumuh, sejatinya juga dipandang oleh komunitas ini sebagai potensi besar untuk meningkatkan ekonomi masyarakat.

Bank Sampah Songolikoer tidak hanya memiliki semangat untuk memberdayakan masyarakat namun juga semangat untuk memperbaiki kampung dengan harapan mendapatkan pahala dari Allah. Bank Sampah ini didirikan oleh kader lingkungan Wonosukumo Kidul dengan didampingi oleh tim Pengabdian Masyarakat dari salah satu perguruan tinggi keagamaan Islam swasta di Surabaya. Anggota kader lingkungan kebanyakan berasal dari anggota Remaja Masjid Ar-Rahman, Wonokusumo Kidul, Surabaya yang memiliki kepedulian untuk membenahi dan membersihkan kampung dengan semangat lillahi ta'ala. Sasaran pemberdayaan masyarakat yang dilakukan oleh Bank Sampah Songolikoer adalah masyarakat Wonokusumo Kidul yang sebagian besarnya beragama Islam.

Adapun pertimbangan memfokuskan kajian pada aspek strategi komunikasi stakeholder yang digunakan dalam pendirian Bank Sampah Songolikoer antara lain: Pertama, kegiatan pemberdayaan masyarakat Islam mutlak membutuhkan dukungan moral dan sosial dari seluruh elemen masyarakat, untuk memastikan masyarakat bersedia terlibat berpartisipasi aktif dalam kegiatan Bank Sampah, mengurangi konflik-konflik kepentingan antara berbagai stakeholder maupun untuk menjamin keberlangsungan kegiatan Bank Sampah secara jangka panjangnya.

Kedua, keberhasilan pendirian Bank Sampah Songolikoer tidak dapat dilepaskan dari strategi komunikasi stakeholder yang dilaksanakan oleh pengurus Bank Sampah Songolikoer. Dalam memberdayakan masyarakat Islam di wilayah Wonokusumo Kidul, Bank Sampah Songolikoer mendapatkan tantangan dari berbagai stakeholder yang memiliki kepentingan secara ekonomis terhadap sampah. Beberapa pihak khawatir pendapatan mereka akan berkurang dengan adanya Bank Sampah. Stakeholder ini memandang bahwa Bank Sampah merupakan kompetitor dari pekerjaan mereka sebagai pengepul sampah. Tak jarang pihak yang memiliki kepentingan ekonomis terhadap sampah juga merupakan tokoh masyarakat yang memiliki pengaruh besar untuk kelangsungan kegiatan kemasyarakatan di Wonokusumo Kidul.

Selain itu, dalam pengembangan Bank Sampah juga membutuhkan dukungan masyarakat sebagai stakeholder yang akan 
menjadi nasabah Bank Sampah. Masyarakat Wonokusumo Kidul belum menyadari prospektus dari kegiatan Bank Sampah, ada beberapa masyarakat yang memandang bahwa adanya Bank Sampah dapat berpotensi menimbulkan penyakit (misal: demam berdarah), sehingga perlu ada komunikasi stakeholder kepada masyarakat agar menerima keberadaan dari Bank Sampah. Oleh karena itu, pada tahap awal pendirian Bank Sampah Songolikoer memfokuskan pada merumuskan maupun melaksanakan strategi komunikasi stakeholder guna menjamin adanya dukungan dari berbagai stakeholder yang ada di sekitar Wonokusumo Kidul.

Pada awal pendiriannya, Pengurus Bank Sampah Songolikoer melakukan komunikasi kepada masing-masing stakeholder, baik yang memiliki kepentingan negatif maupun positif terhadap pendirian Bank Sampah. Strategi komunikasi stakeholder yang diterapkan pada masing-masing stakeholder berbeda-beda, baik melalui forum maupun komunikasi personal pada masing-masing stakeholder. Dari pelaksanaan strategi komunikasi kepada stakeholder tersebut, banyak tokoh dan masyarakat di wilayah tersebut setuju terhadap berdirinya Bank Sampah. Pada awal pendiriannya, terdapat 16 nasabah yang bergabung dalam Bank Sampah Songolikoer, serta dihadiri dan didukung oleh berbagai tokoh masyarakat (Ketua RT, RW, termasuk salah satu tokoh masyarakat yang sebelumnya menolak berdirinya Bank Sampah).

\footnotetext{
5 Muzani, "Strategi Peningkatan Peran Stakeholder Dalam Pengelolaan Mangrove di Kabupaten Tanggerang," SPATIAL Wahana Komunikasi dan Informasi Geografi Vol. 12 No. 2 (2014): 21-27.

${ }^{6}$ Dwi Lestari dan Mohammad Muktiali, "Peran Pemangku Kepentingan dalam Pengembangan Klaster
}

Ketiga, belum ditemukan studi terdahulu yang membahas terkait strategi komunikasi stakeholder yang digunakan dalam kegiatan pemberdayaan masyarakat Islam. Beberapa studi terdahulu membahas tentang stakeholder dalam konteks pengembangan masyarakat antara lain: 1) Strategi Peningkatan Peran Stakeholder Dalam Pengelolaan Mangrove Di Kabupaten Tanggerang, $^{5} \quad$ 2) Peran Pemangku Kepentingan dalam Pengembangan Klaster Enceng Gondok di Kecamatan Banyubiru, ${ }^{6} 3$ ) Strategi Mengelola Program Organisasi Dengan Dukungan Seluruh Stakeholder Terkait Dengan Pendekatan Net Mapping Pada Penyusunan Proyek Perubahan Diklat PIM IV Pola Baru. ${ }^{7}$ Dari penelitian-penelitian tersebut lebih banyak mendeskripsikan peranan stakeholder dalam keberhasilan kegiatan pengembangan masyarakat dan langkah mapping/pemetaan stakeholder. Namun, tidak sedikitpun menguraikan tentang strategi komunikasi yang relevan dalam membangun hubungan yang harmonis pada para stakeholders tersebut. Padahal untuk meningkatkan partisipasi stakeholder dalam kegiatan pemberdayaan masyarakat dibutuhkan strategi komunikasi stakeholder yang tepat. Jika strategi komunikasi komunikasi kepada stakeholder yang digunakan keliru, justru dapat memperburuk hubungan organisasi dengan para stakeholder ataupun mengakibatkan tidak adanya kesejalanan kepentingan antara berbagai pemangku kepentingan.

Enceng Gondok di Kecamatan Banyubiru," Jurnal Wilayah dan Lingkungan, Vol. 5 No. 3 (2017): 141-155. ${ }^{7}$ Eva Faza Rif'ati, "Strategi Mengelola Program Organisasi Dengan Dukungan Seluruh Stakeholder Terkait Dengan Pendekatan Net Mapping pada Penyusunan Proyek Perubahan dalam Diklat PIM IV Pola Baru," Forum Manajemen, Vol. 06. No. 02. 10-20. 
Adapun penelitian tentang komunikasi stakeholder pernah dilakukan oleh Dorien Kartikawangi, yang mana hanya melihat pada aspek komunikasi interelasinya antarpemangku kepentingan. ${ }^{8}$ Penelitian Dorien tidak membahas tentang bagaimana organisasi merancang strategi komunikasi yang sesuai dalam menghadapi berbagai jenis stakeholder. Selain itu, penelitian tersebut juga masih berangkat dari literatur teori-teori terkait, bukan berangkat dari realitas empiris strategi komunikasi yang diterapkan dalam lapangan pengembangan masyarakat Islam.

Dari beberapa latar belakang di atas, penelitian ini memiliki rumusan masalah: "Bagaimana strategi komunikasi pada stakeholder yang diterapkan oleh pengurus Bank Sampah Songolikoer dalam pendirian Bank Sampah Songolikoer?"

Studi ini menggunakan pendekatan kualitatif lapangan. Kualitatif dikarenakan tujuan dari studi ini adalah untuk mengurai stakeholderstakeholder yang terdapat dalam kegiatan pemberdayaan masyarakat Islam dalam bentuk Bank Sampah, serta menggambarkan pola-pola strategi komunikasi stakeholder yang diterapkan oleh Bank Sampah Songolikoer untuk meraih dukungan dalam mendirikan Bank Sampah. Merupakan penelitian lapangan dengan menggunakan wawancara semi terstruktur dan observasi partisipan. Informan ditetapkan secara purposive, dipilih berdasarkan kriteria pihakpihak yang dipandang mengetahui terkait dengan aset komunitas yang terdapat di

8 Dorien Kartikawangi, "Kolase Komunikasi di Indonesia (Komunikasi Akomodasi dan Konvergensi Simbolis Dalam Interelasi Pemangku Kepentingan)," ASPIKOM (2017), 3-20.

9 Rachmat Krisyantono, Teknik Praktis Riset Komunikasi: Disertai Contoh Praktis Riset Media, Public wilayah Wonokusumo Kidul serta peranannya selama ini dalam pendirian Bank Sampah Songolikoer. Informan dalam studi ini adalah: (1) Ketua Bank Sampah Songolikoer; (2) Ketua RW Wonokusumo Kidul; (3) Ketua Kader Lingkungan Wonokusumo Kidul; (4) Salah satu penggagas Bank Sampah Wonokusumo Kidul. Dalam proses pengumpulan data, periset adalah bagian integral dari data yang secara aktif menjadi instrumen untuk terjun ke lapangan secara mendalam. ${ }^{9}$ Analisis data menggunakan model Miles dan Huberman yaitu melalui reduksi data, displai data dengan pola sesuai dengan tema-tema yang dipandang terkait dengan penelitian ini, dan terakhir adalah verifikasi (triangulasi data sumber), analisis dan penarikan kesimpulan. ${ }^{10}$ Proses pemilahan dan penyajian data berdasarkan temuan stakeholder yang ada beserta jenis kepentingan (positif/negatif terhadap tujuan organisasi), tingkat kepentingan dan pengaruhnya. Selain itu, juga menguraikan strategi komunikasi pada stakeholder yang diterapkan dan pertimbangannya. Interpretasi data dan penarikan kesimpulan dipandu dengan teori strategi komunikasi stakeholder.

\section{Pemberdayaan Masyarakat Islam}

Pemberdayaan masyarakat Islam merupakan usaha untuk mendorong keinginan, upaya, dan partisipasi masyarakat dalam melakukan perubahan. ${ }^{11}$

Relation, Advertising, Komunikasi Organisasi, Komunikasi Pemasaran, (Jakarta: Kencana, 2010), 57. ${ }^{10}$ Sugiyono, Metode Penelitian Kuantitatif, Kualitatif Dan R\&D, (Bandung: Alfabeta, 2015), 246-252.

${ }^{11}$ Faizal, "Dakwah Bil Hal Dalam Perspektif Al-Qur'an," Jurnal Alummah, Vol. 8, No. 2, (2014): 255-267. 
Pemberdayaan masyarakat adalah usaha meningkatkan kapasitas masyarakat agar dapat memecahkan permasalahan dan memenuhi kebutuhan hidupnya dengan kemampuannya sendiri secara mandiri. ${ }^{12}$ Kegiatan pemberdayaan masyarakat merupakan perwujudan dakwah bilhal. Setidaknya terdapat tiga cara pelaksanaan dakwah bilhal yang dapat ditempuh. Pertama, dakwah pembinaan tenaga/sumber daya manusia; kedua, lewat pengembangan institusi; ketiga lewat pengembangan infrastruktur. ${ }^{13}$ Dari pengertian tersebut, kegiatan pemberdayaan masyarakat Islam melalui Bank Sampah dapat dimaknai sebagai perwujudan dakwah bilhal dengan meningkatkan kapasitas manusia, mengembangkan institusi dan infrastruktur masyarakat untuk mewujudkan lingkungan dan kesejahteraan ekonomi yang lebih baik.

\section{Stakeholder/Pemangku Kepentingan}

Pemangku kepentingan adalah semua anggota masyarakat baik yang bersifat perorangan maupun kelompok atau bahkan organisasi dan sejenisnya yang dianggap memiliki peran atau pengaruh dalam kegiatan suatu usaha, bisnis, atau industri. ${ }^{14}$ Stakeholder adalah siapa saja yang secara langsung atau tidak langsung terpengaruh oleh suatu proyek/aktivitas yang

\footnotetext{
12 Isbandi Rukmianto Adi, Intervensi Komunitas \& Pengembangan Masyarakat Sebagai Upaya Pemberdayaan Masyarakat, (Jakarta: PT. Raja Grafindo Persada, 2013), 205.

13 Nanih Machendrawaty dan Agus Ahmad Safei, Pengembangan Masyarakat Islam, (Bandung: PT. Remaja Rosdakarya, 2001), 161.

14 Dwi Lestari dan Mohammad Muktiali, "Peran Pemangku Kepentingan," 145.

15 Stakeholder Engagement Handbook, (Paris: Biodiversa, 2014), 12.
}

dilaksanakan oleh organisasi. Stakeholder juga bisa berupa siapa saja yang memiliki kepentingan terhadap proyek/kegiatan organisasi, serta memiliki kemampuan untuk memengaruhi positif/negatifnya kegiatan/proyek yang sedang dilaksanakan organisasi. ${ }^{15}$ Stakeholder dapat berasal dari dalam maupun luar organisasi. Dalam konteks bisnis, stakeholder utama terdiri dari tiga kelompok yaitu: pemegang saham, pelanggan, dan karyawan. ${ }^{16}$ Masing-masing kelompok pemangku kepentingan memiliki kekuatan, legitimasi, dan urgensi yang berbeda-beda. ${ }^{17}$ Selain itu, pemangku kepentingan dapat berasal dari masyarakat, tokoh masyarakat, tokoh agama, pejabat organisasi publik/swasta maupun akademisi yang berpengaruh ataupun terpengaruh oleh sebuah kebijakan/program/kegiatan organisasi dalam rangka memberikan addedvalue kepada masyarakat. ${ }^{18}$

Klasifikasi tentang jenis-jenis stakeholder berdasarkan kepentingan (interest) dan kekuatan pengaruhnya (power) antara lain: ${ }^{19}$

Tabel 1 - Jenis-Jenis Stakeholder

\begin{tabular}{lcc}
\hline \multicolumn{1}{c}{ Jenis } & Kepentingan & Pengaruh \\
\hline \hline $\begin{array}{l}\text { Subject Stakeholder } \\
\text { Key Player }\end{array}$ & Tinggi & Rendah \\
$\begin{array}{l}\text { Stakeholder } \\
\text { Context Setter } \\
\text { Stakeholder }\end{array}$ & Tinggi & Tinggi \\
Crowd Stakeholder & Rendah & Tinggi \\
\hline
\end{tabular}

16 Klaus Oestreicher, Strategic Communication and the Stakeholder Concept: Merging Marketing Communication and $P R$, (United Kingdom: Henwick Grove, Worcester WR2 6AJ, 2009), 4.

17 Ibid, 8

18 Eva Faza Rif'ati, "Strategi Mengelola Program Organisasi," 13-14.

19 Muzani, "Strategi Peningkatan Peran Stakeholder," 23. 
Berdasarkan jenis kepentingan (positif dan negatif) dan kualitas pengaruhnya terhadap organisasi atau program pemberdayaan masyarakat maka ada beberapa klasifikasi jenis stakeholder antara lain: ${ }^{20}$ (1) positivepowerful: key player stakeholder yang mendukung proyek/program pemberdayaan masyarakat, kelompok kepentingan ini memiliki cukup pengaruh untuk melakukan perubahan; (2) positive-weak: stakeholder yang mendukung program pemberdayaan masyarakat, namun memiliki pengaruh yang lemah atau bahkan tidak memiliki pengaruh terhadap pelaksanaan program. Kelompok kepentingan yang semacam ini perlu diberi informasi yang memadai untuk dapat mempertahankan dukungan mereka dan mendorong mereka untuk mempromosikan program; (3) negative-powerful: Kelompok kepentingan yang tidak mendukung tujuan program pemberdayaan yang dilaksanakan, namun memiliki pengaruh yang kuat. Stakeholder yang semacam ini perlu diidentifikasi sebagai risiko untuk proyek dan perlu membangun hubungan yang baik untuk mengurangi potensi dampak yang bersifat merusak program pemberdayaan yang dilaksanakan; (4) negative-weak: stakeholder yang memiliki pengaruh kecil atau bahkan tidak memiliki pengaruh, tetapi juga tidak mendukung tujuan program. Para stakeholder semacam ini harus terus diberi informasi tentang perkembangan program.

Untuk dapat mengategori stakeholders ke dalam jenis-jenis di atas maka sangat diperlukan pemahaman terhadap kepentingan stakeholder terhadap program dari organisasi publik tersebut. Kepentingan

20 Communication Management \& Stakeholder Engagement, Delivering Successful Change, Version 3.1, Section E, (Leeds City Council, tt.), 4-5. stakeholder dapat berupa: kepentingan ekonomi, politik, etnis, lingkungan, keamanan, sosial, budaya, dan lain sebagainya. Sedangkan sikapnya terhadap program yang dilaksanakan dapat berupa menunjukkan sikap mendukung, menolak secara terang-terangan karena bertentangan dengan kepentingan mereka, atau abstain. ${ }^{21} \quad$ Analisis stakeholder diperlukan untuk mengetahui: (1) siapa saja aktor/kelompok kepentingan/stakeholders yang terlibat? (2) bagaimana antarkelompok kepentingan saling terhubung? (3) seberapa besar pengaruh masing-masing stakeholder terhadap program pemberdayaan masyarakat? (4) apakah tujuan/kepentingan para pemangku stakeholder?

\section{Strategi Komunikasi Stakeholder}

Strategi komunikasi secara umum dapat memiliki beberapa tujuan antara lain: memengaruhi orang lain untuk menerima gagasan kita, membangun relasi antarpersonal, membangun link ke dunia sekitar (kelompok, organisasi, dan masyarakat) dan lain sebagainya. ${ }^{22}$ Strategi komunikasi stakeholder dapat dimaknai dengan strategi komunikasi yang diterapkan kepada masing-masing stakeholder sasaran dalam rangka membangun interaksi positif antara organisasi/perusahaan dengan berbagai stakeholder yang ada (stakeholder engagement). Hubungan yang baik antara organisasi/perusahaan dengan stakeholder sangatlah penting, karena dapat mengurangi hambatan pada aktivitas organisasi, meningkatkan izin untuk beroperasi, meminimalkan risiko, dan meningkatkan

\footnotetext{
${ }^{21}$ Eva Faza Rif'ati, Strategi Mengelola Program Organisasi, 14.

${ }^{22}$ Alo Liliweri, Komunikasi: Serba Ada Serba Makna, (Jakarta: Kencana, 2011), 128.
} 
peluang dengan memahami konteks lingkungan, sosial, ekonomi, politik, teknologi secara utuh dan cepat berubah, serta dapat mengatasi kritik yang disampaikan oleh stakeholder. ${ }^{23}$

Tujuan utama komunikasi pemangku kepentingan antara lain: (1) mempertimbangkan, memetakan pemangku kepentingan dan menentukan opsi keterikatan yang sesuai dengan kondisi masing-masing stakeholder; (2) membangun konsensus dan mengurangi konflik di masa depan dengan keterlibatan berbagai stakeholder; (3) keterlibatan para pemangku kepentingan, sehingga memungkinkan berbagi pengetahuan dan keahlian antara pemangku kepentingan dan organisasi; (4) mengidentifikasi dan mengatasi kekhawatiran pemangku kepentingan; (5) mengembangkan komunikasi dua arah antara stakeholder internal dan eksternal; (6) memastikan pemahaman bersama tentang masalah dan tujuan organisasi. ${ }^{24}$ Komunikasi terhadap pemangku kepentingan perlu dibedakan pada masingmasing kelompok pemangku kepentingan. $\mathrm{Hal}$ itu dikarenakan masing-masing stakeholder memiliki pengaruh dan minat (kepentingan) yang berbeda dan beragam terhadap tujuan organisasi. ${ }^{25}$ Strategi komunikasi stakeholder terdiri dari beberapa komponen antara lain: (1) What (high quality research analysis, opinions: key Messages), (2) To Whom (stakeholder mapping), (3) How (communication strategy and means:

\footnotetext{
${ }^{23}$ Neil Jeffery, Stakeholder Engagement: A Road Map to Meaningful Engagement, (Doughty Centre, Cranfield School of Management, 2009), 11.

24 Water Affairs Republic Of Africa, Stakeholder Communication Strategy to Support the CMAs Establishment Project, (South Africa: 2012), 4.

${ }^{25}$ Klaus Oestreicher, Strategic Communication and the Stakeholder Concept, 8.
}

products, tools, channels), (4) When (identification of relevant/appropriate timing for stakeholders). ${ }^{26}$

Organisasi perlu merancang strategi komunikasi stakeholder secara efektif agar stakeholder dapat mendukung organisasi dalam mencapai tujuan dan sasaran organisasi, meningkatkan efektivitas operasionalisasi tujuan organisasi, serta membangun hubungan dengan key stakeholder atau target audiens untuk menunjang keberhasilan organisasi. ${ }^{27}$ Ada beberapa langkah dalam merancang strategi komunikasi stakeholder antara lain: (1) menetapkan tujuan komunikasi stakeholder; (2) mengatur pesan utama yang ingin dikomunikasikan organisasi; (3) menentukan dan membuat prioritas stakeholder utama organisasi; (4) menetapkan pesan utama dan tambahan yang relevan untuk masingmasing kelompok pemangku kepentingan sesuai dengan masalah dan kepentingan khusus mereka; (5) mengembangkan taktik komunikasi yang efektif untuk setiap target audiens; (6) mengalokasikan anggaran dan tanggung jawab untuk melaksanakan strategi komunikasi stakeholder yang telah dirumuskan; (7) mengatur skedul pelaksanaan strategi komunikasi stakeholder; (8) mengevaluasi hasil pelaksanaan strategi komunikasi stakeholder dan mengadaptasi rencana baru. ${ }^{28}$

\footnotetext{
${ }^{26}$ FRA Stakeholder Communication Framework 20112013, (FRA European Union Agency For Fundamental Right, 2011), 2.

${ }^{27}$ Creating a Stakeholder Communications Plan, (New Zealand: SPARC Ihi AOTEAROA, 2006), 3 www.sparc.org.nz

28 Ibid, 4.
} 
Dalam konteks ini, strategi komunikasi stakeholder tujuannya adalah bagaimana para stakeholder di sekitar Bank Sampah Songolikoer dapat menerima/menyetujui, mendukung gagasan, dan pelaksanaan kegiatan pemberdayaan masyarakat, ditandai dengan berdirinya Bank Sampah. Tujuan-tujuan lain yang dapat dicapai dalam strategi komunikasi stakeholder antara lain: (1) sebagai upaya untuk terus memberikan informasi pada pemangku kepentingan agar mendukung program pemberdayaan masyarakat yang sedang dilaksanakan, baik berupa informasi kondisi sebelum program maupun kemajuan setelah pelaksanaan program; (2) memberi informasi pada pemangku kepentingan tentang bagaimana memberikan kontribusi dalam program pemberdayaan masyarakat yang dilaksanakan; (3) membangun komitmen dari para stakeholder untuk mendukung program. Hal ini diperlukan agar memastikan keberhasilan dan keberlanjutan program jangka panjang, dan lain sebagainya. ${ }^{29}$ Tujuan akhir studi dari mengkaji bentuk strategi komunikasi stakeholder yaitu adanya kerja sama yang berkesinambungan antarpihak pemangku kepentingan, sehingga kegiatan pemberdayaan masyarakat Islam dapat berjalan secara lancar.

Yasin Ilyas yang mengadaptasi dari Quick membagi pola-pola komunikasi ke dalam empat spektrum yaitu agresif, asertif, responsif, dan nonasertif. Spektrum ini memungkinkan pula digunakan untuk menganalisis strategi komunikasi stakeholder yang diterapkan oleh Bank

${ }^{29}$ Leeds City Council.; Communication Management \& Stakeholder Engagement, 6-7.

30 Badan Diklat DIY, "Membangun Tim Efektif Bahan Ajar Diklat Kepemimpinan Aparatur Pemerintah
Sampah Songolikoer. Berikut adalah deskripsi dari setiap spektrum tersebut: ${ }^{30}$

Pertama, strategi komunikasi agresif. Strategi komunikasi agresif cenderung memfokuskan pada kepentingan lembaga/subjek yang melaksanakan program pemberdayaan masyarakat dibandingkan dengan stakeholder luar lainnya. Karakteristik strategi komunikasinya cenderung menggunakan pernyataan yang bersifat merendahkan stakeholder lainnya bahkan mungkin bersifat mengancam.

Kedua, strategi komunikasi asertif. Sama halnya dengan komunikasi yang bersifat agresif, kelompok kepentingan di luar organisasi dipandang sebagai nomor dua. Sedangkan kepentingannya sendiri sebagai yang utama. Dalam berkomunikasi, strategi ini cenderung berfokus pada menyampaikan kebutuhan, kepentingannya dengan cara yang masih dapat diterima/direspon positif oleh para stakeholder. Kelompok kepentingan di luar lembaga memungkinkan menerima informasi yang bersifat tidak menyenangkan/berbeda dengan kepentingan mereka, tetapi dengan cara yang tidak mengancam dan tidak membuat para stakeholders merasa diejek. Strategi asertif menggunakan cara yang tidak mengancam biasanya dalam bentuk: memberikan informasi tentang kondisi permasalahan yang sedang terjadi, menjelaskan perilaku yang diinginkan organisasi pada stakeholder ini, menjelaskan manfaat-manfaat perubahan yang akan diperoleh dengan tujuan mengikuti kepentingan internal organisasi.

Tingkat III", (Jakarta: Lembaga Administrasi Negara Republik Indonesia, 2013), http://diklat.jogjaprov.go.id 
Ketiga, strategi komunikasi responsif. Strategi komunikasi ini cenderung menganggap stakeholder lain adalah yang utama, sedangkan kepentingan lembaga/agen pemberdayaan masyarakat justru menjadi yang sekunder. Dalam konteks komunikasi ini, lembaga/subjek pemberdayaan masyarakat sadar bahwa masing-masing stakeholder memiliki kekuatan, kepentingan, sumber daya, dan persepsi yang beragam dalam menyikapi kondisi tertentu khususnya dihubungkan dengan program pengembangan masyarakat yang dilaksanakan. Strategi komunikasi ini cenderung mencari dan mengidentifikasi berbagai pertimbangan untuk dapat mempertemukan kesamaan kepentingan/pandangan terhadap program yang dilaksanakan. Hal itu dilakukan dengan mengidentifikasi kepentingan dan perasaan masing-masing stakeholder terhadap program pemberdayaan yang akan dilaksanakan tanpa harus membuat mereka sependapat dengan organisasi/agen pemberdayaan masyarakat. Dalam strategi ini organisasi/agen pemberdayaan masyarakat bersedia untuk mengubah aspek-aspek internal, untuk tetap membangun relasi yang baik dengan berbagai pihak-pihak stakeholder lainnya namun tetap berupaya menjelaskan manfaat/insentif bagi stakeholder lainnya jika memungkinkan bagi kedua belah pihak.

Keempat, strategi komunikasi nonasertif. Strategi komunikasi ini cenderung memandang bahwa kelompok kepentingan yang ada di luar lembaganya sebagai segalanya. Sehingga semua tanggung jawab bahkan kepentingan mengikuti kepentingan stakeholder luarnya. Strategi komunikasinya cenderung bersifat mengalah dan mengikuti kepentingan stakeholder lainnya.

Strategi komunikasi menurut llyas masih memungkinkan dipadukan satu sama lainnya, misalnya strategi responsif dan asertif yang biasanya digunakan dalam situasi adanya kebutuhan resolusi konflik/negosiasi dengan berbagai stakeholder. Jika strategi responsif dan asertif digunakan maka akan menjamin terbukanya ruang dialog kepentingan antarberbagai stakeholders.

\section{Bank Sampah Songolikoer}

Bank Sampah Songolikoer berdiri pada tanggal 18 Januari 2019. Bank Sampah Songolikoer menyelenggarakan kegiatan pemberdayaan masyarakat Islam dalam bentuk sosialisasi untuk meningkatkan kesadaran akan memilah sampah, melaksanakan administrasi kegiatan Bank Sampah, melaksanakan pemilahan dan penimbangan sampah secara rutin, penyetoran sampah ke Bank Sampah Induk Surabaya (BSIS) secara reguler tiap dwimingguan, serta menyimpan dan membagikan uang pendapatan dari sampah kepada nasabah sesuai kesepakatan. Nama Bank Sampah Songolikoer dipilih mengingat Bank Sampah ini berdiri di kampung Wonokusumo Kidul yang hampir sebagian besar nomor rumah warganya adalah 29, dalam bahasa Jawa Surabaya disebut songolikur. Masyarakat Wonokusumo Kidul merupakan masyarakat yang sebagian besarnya beragama Islam, kegiatan-kegiatan yang bersifat keislaman cukup hidup di sana seperti: pengajian, remaja masjid, kegiatan peringatan hari besar Islam dan lain sebagainya. Masyarakat banyak berasal dari Madura, yang mana juga sangat menjunjung 
nilai-nilai Islam dan menyegani tokoh agama yang ada di masyarakat. Jumlah nasabah awal Bank Sampah Songolikoer sekitar 20-an orang, kemudian berkembang sampai sekarang menjadi 61 orang nasabah, ratarata adalah ibu-ibu.

\section{Pemetaan Stakeholder Berdasarkan Pada Jenis, Tingkat Kepentingan, dan Kekuatan Pengaruhnya}

Sebelum merumuskan strategi stakeholder yang akan digunakan, pengurus Bank Sampah Songolikoer melaksanakan pemetaan terhadap stakeholder yang terkait dengan pendirian Bank Sampah. Ada beberapa stakeholder yang dipetakan oleh pengurus Bank Sampah Songolikoer antara lain: Masyarakat yang sebelum adanya Bank Sampah telah mengumpulkan sampah untuk mendapatkan tambahan pendapatan (pengepul), tokoh masyarakat sekitar (RT, RW, Lurah, Camat), Stakeholder internal (anggota kader lingkungan), mitra kerja sama (Bank Sampah Induk Surabaya), kelompok sosial masyarakat yang ada di Wonokusumo Kidul dan terkait dengan Bank Sampah (remaja masjid dan PKK) serta pesaing (tukang rombeng). Hasil identifikasi stakeholder ditemukan beberapa jenis stakeholder berdasarkan jenis kepentingan (positif dan negatif) dan tingkat kepentingannya antara lain:

\section{1) Subject Stakeholder}

Dalam pendirian Bank Sampah terdapat stakeholder yang kategorinya adalah subject stakeholder yaitu Warga Wonokusumo Kidul yang sebelumnya sudah bekerja mengumpulkan sampah. Masyarakat ini dapat dikatakan memiliki kepentingan yang tinggi dan negatif terhadap pendirian Bank Sampah. Namun, secara pengaruhnya lemah. Mereka menerima efek langsung dari berdirinya Bank Sampah, berpotensi merasa berkurangnya pendapatan dari sampah yang sebelumnya dikumpulkan. Ada beberapa hal yang dikhawatirkan oleh stakeholder ini dengan didirikannya Bank Sampah antara lain: a) khawatir akan berkurangnya hasil sampah yang dikumpulkan sebab harus bersaing dengan masyarakat ataupun pengurus Bank Sampah. Mereka menyebut bahwa adanya Bank Sampah pasti akan menjadi pesaing mereka; b) khawatir harga jual di Bank Sampah lebih rendah dari harga jual di pengepul atau rombeng, sehingga jika mereka ikut menjadi nasabah Bank Sampah justru merugi; c) kekhawatiran jika menjual sampahnya di Bank Sampah tidak mendapatkan uang secara cash, sebab sistem Bank Sampah adalah tabungan. Padahal kebanyakan mereka adalah masyarakat menengah bawah yang sering pula membutuhkan uang tersebut secara langsung. Meskipun masyarakat ini memiliki kepentingan yang tinggi terkait pendirian Bank Sampah, namun sebagian besarnya cenderung tidak secara langsung menyampaikan kekhawatirannya, sehingga pengaruhnya tidak terlalu besar. Meskipun terdapat satu orang yang cukup kuat pengaruhnya karena merupakan tokoh masyarakat (yang akan dibahas pada bagian berikutnya).

\section{2) Keyplayer Stakeholder}

Terdapat berbagai bentuk keyplayer stakeholder dalam pendirian Bank Sampah Songolikoer. Keyplayer stakeholder berarti stakeholder yang memiliki kepentingan dan pengaruh tinggi dalam pendirian Bank Sampah. Ada yang kepentingannya bersifat positif (positive keyplayer stakeholder) dan ada pula yang kepentingannya negatif (negative keyplayer stakeholder). 
Stakeholder yang memiliki kepentingan positif tinggi dan pengaruh kuat terhadap Bank Sampah ada beberapa pihak antara lain: 1) masyarakat Wonokusumo Kidul sebagai penerima manfaat yang memiliki kepentingan meningkatkan pemasukan ekonomi melalui sampah. Pengaruhnya kuat terhadap Bank Sampah sebab partisipasinya akan memengaruhi jumlah nasabah Bank Sampah dan jumlah sampah yang ditargetkan terkumpul pada tahap awal; 2) Ketua RW memiliki kepentingan kuat terhadap pendirian Bank Sampah sebab beliau merupakan penggagas Bank Sampah. Pengaruh Ketua RW kuat karena merupakan tokoh masyarakat yang disegani; 3) BSIS (Bank Sampah Induk Surabaya), yang memiliki kepentingan agar setiap tempat di Surabaya memiliki Bank Sampah dan terorganisasi dalam Bank Sampah Induk Surabaya. Pengaruhnya kuat sebagai mitra Bank Sampah Songolikoer yang dapat membantu pengembangan Bank Sampah, khususnya pada tahap awal pelaksanaan; 4) anggota kader lingkungan juga memiliki kepentingan yang kuat sebab merupakan pendiri Bank Sampah Songolikoer. Pengaruhnya juga kuat mengingat kader lingkungan Wonokusumo Kidul, sebagai agen pemberdayaan masyarakat dalam kegiatan ini. Sedangkan yang termasuk Keyplayer Stakeholder namun kepentingannya negatif adalah salah satu tokoh masyarakat yang selama ini sudah berprofesi mengumpulkan sampah untuk menambah penghasilannya. Dengan adanya Bank Sampah beliau khawatir akan mengurangi pendapatan yang sudah diperoleh selama ini. Secara pengaruh juga kuat di masyarakat sebab beliau adalah tokoh agama yang cukup vokal menyampaikan aspirasi-aspirasinya.

\section{3) Context Setter Stakeholder}

Context Stakeholder adalah stakeholder yang memiliki kepentingan tinggi dan tingkat pengaruhnya kuat terhadap Pendirian Bank Sampah. Adapun kepentingannya yang bersifat positif ada beberapa pihak antara lain: 1) Lurah dan Camat di wilayah domisili Bank Sampah. Lurah dan Camat setempat memiliki kepentingan agar masing-masing RW memiliki Bank Sampah sebagaimana harapan Wali Kota Surabaya namun sejauh ini tidak terlalu intensif disosialisasikan; 2) Ketua RT-02, Ketua RT cenderung mendukung kegiatan Bank Sampah karena memberikan manfaat bagi warganya, tetapi beliau tidak secara aktif dalam kegiatan lingkungan yang dilaksanakan di kampung Wonokusumo Kidul yang notabenenya tingkat RW. Meskipun tidak ada tindakan aktif dari lurah, camat, maupun ketua RT dalam mendukung kegiatan Bank Sampah, namun pengaruhnya kuat dalam menentukan izin pendirian Bank Sampah Songolikoer di wilayah Wonokusumo Kidul.

Dalam pengembangan Bank Sampah tidak dapat dilepaskan dari kelompok sosial masyarakat yang ada di kawasan Wonokusumo Kidul yaitu Remaja Masjid ArRahman dan kader Posyandu. Hal itu mengingat sebagian besar anggota dari kader lingkungan juga merupakan anggota dari remaja masjid dan kader Posyandu. Terdapat pula yang merupakan anggota remaja masjid dan kader Posyandu tetapi tidak mengikuti kader lingkungan ataupun Bank Sampah. Meskipun dua kelompok sosial ini memiliki sebagian kepentingan yang sama yaitu ingin memberikan manfaat bagi masyarakat, namun ada tujuan/kepentingan spesifik yang berbeda, kegiatan-kegiatan dan keanggotaan yang berbeda dengan Bank Sampah. Tak jarang 
sebagian anggota kader lingkungan merasa iri dengan anggota remaja masjid yang tidak aktif dalam kegiatan Bank Sampah dan bisa bersantai-santai hanya mengikuti kegiatan remaja masjid saja, maupun sebaliknya, ada pula potensi persoalan konflik kepentingan dan jadwal kegiatan antara kelompok sosial tersebut (Remaja Masjid Ar-Rahman dan kader Posyandu) dengan kegiatan Bank Sampah, ditambah lagi ada kepengurusan dan ketua yang berbeda di antara kelompok sosial tersebut yang memungkinkan terjadi konflik-konflik kepentingan.

\section{4) Crowd Stakeholder}

Crowd stakeholder adalah stakeholder yang memiliki kepentingan tinggi dan tingkat pengaruhnya rendah terhadap Pendirian Bank Sampah. Crowd stakeholder yang kepentingannya bersifat negatif adalah tukang rombeng. Tukang rombeng memiliki kepentingan yang mirip dalam hal mengumpulkan sampah. Dengan adanya Bank Sampah pasti akan mengurangi pemasukan sampah yang diperoleh oleh tukang rombeng di wilayah Wonokusumo Sekalipun ada kepentingan ekonomi dengan tukang rombeng, namun kepentingan ini tidak terlalu besar, mengingat selama ini hanya sedikit warga yang peduli mengumpulkan sampah dan menjual pada tukang rombeng, sehingga masyarakat Wonokusumo Kidul bukan pasar utama bagi Rombeng. Selain itu, tukang rombeng merupakan masyarakat di luar Wonokusumo Kidul, serta selama ini tidak datang secara rutin, hanya pada hari-hari tertentu di kawasan Wonokusumo Kidul. Dalam satu bulan paling sekali atau dua kali ada Rombeng yang datang di wilayah Wonokusumo Kidul.

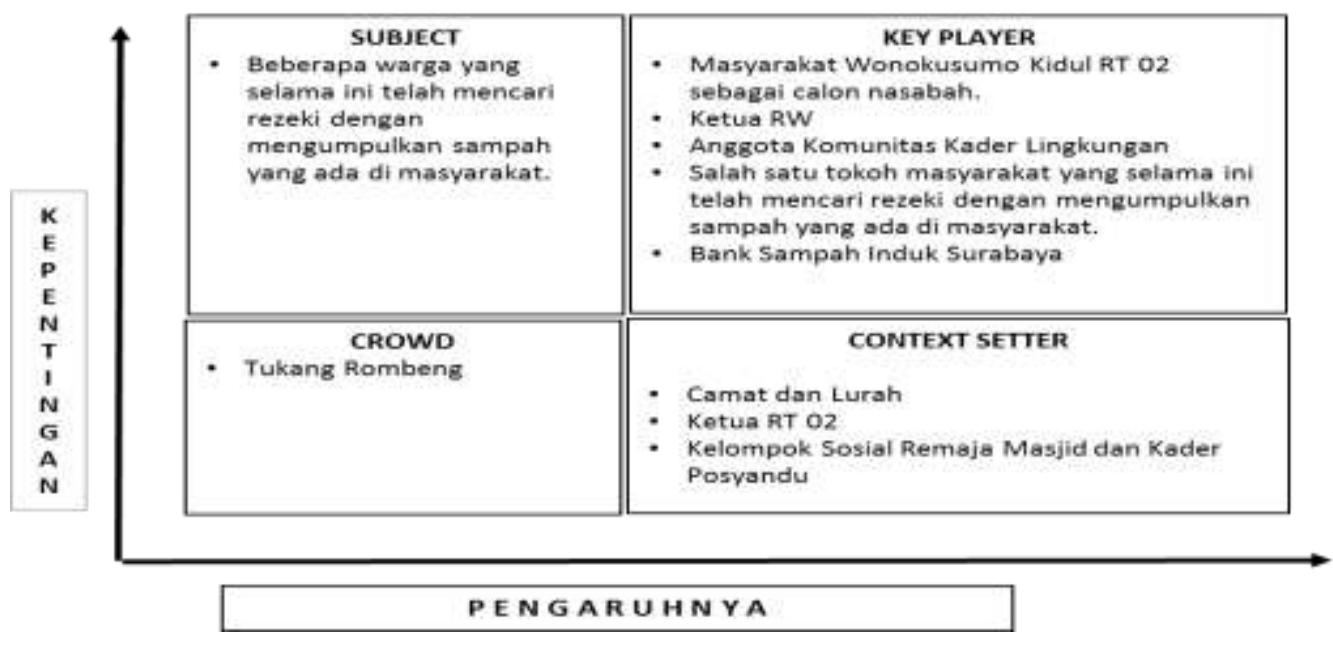

Gambar 1.1. Matriks kepentingan dan pengaruh masing-masing jenis stakeholder 


\section{Strategi Komunikasi Stakeholder Dalam Pendirian Bank Sampah Songolikoer}

Pembahasan strategi komunikasi meliputi rancangan strategisnya, setelah itu masuk ke teknis komunikasi. Sehingga, pada awal pembahasan strategi akan dijelaskan tentang: a. Jenis stakeholder apa saja yang dipilih oleh Bank Sampah Songolikoer serta pertimbangannya; b. Pilihan spektrum komunikasi (strategi komunikasi agresif, asertif, responsif, dan nonasertif) yang digunakan dan pertimbangannya; c. Langkah-langkah teknis komunikasi; d. Respon stakeholder terhadap pendirian Bank Sampah Songolikoer setelah adanya upaya strategi komunikasi stakeholder yang dilaksanakan.

\section{1) Stakeholder Sasaran Komunikasi (Komunikan)}

Sebelum merumuskan strategi komunikasi stakeholder, Pengurus Bank Sampah Songolikoer menetapkan komunikan sasaran komunikasi. Stakeholder sasaran komunikasi baik yang memiliki kepentingan negatif maupun positif. Hal itu dikarenakan kepentingan dan pengaruh yang dimiliki oleh keyplayer stakeholder bersifat kuat menentukan sukses atau gagalnya program pengembangan masyarakat.

Jenis positive key players stakeholder jika memiliki kesamaan pandangan yang kuat untuk berdirinya Bank Sampah dapat menjadi modal utama berdirinya Bank Sampah. Jenis positive key player stakeholder dapat berpotensi menjadi subjek/SDM pengelola Bank Sampah, mitra pendukung Bank Sampah maupun nasabah yang dapat menentukan berdiri atau tidaknya Bank Sampah. Sedangkan, jenis negatif key player stakeholder jika tidak dirangkul dengan baik dapat memusuhi kegiatan Bank Sampah bahkan bisa mengajak masyarakat yang lain untuk tidak setuju dengan pendirian Bank Sampah.

Pengurus Bank Sampah juga memperhatikan stakeholder yang berjenis subject dan context setter. Sekalipun stakeholder berjenis subject pengaruhnya cenderung lemah namun memiliki kekhawatiran/kepentingan yang tinggi terhadap berdirinya Bank Sampah, karena Bank Sampah dipandang sebagai pesaing mereka dalam memperoleh pendapatan dari sampah. Pengurus Bank Sampah melalui strategi komunikasi stakeholder yang dilakukan berupaya agar jangan sampai adanya Bank Sampah justru merugikan pihak-pihak yang selama ini mencari hidup dari sampah dan memicu konflik di masyarakat. Sedangkan stakeholder yang bersifat context setter juga diperhatikan terlebih karena kepentingan mereka cenderung positif meski pengaruhnya rendah. Sehingga adanya komunikasi informatif terhadap jenis context setter stakeholder diharapkan dapat mempertahankan dukungan stakeholder berjenis context setter pada kegiatan pendirian Bank Sampah, khususnya dalam hal mempermudah perizinan pendirian Bank Sampah.

Stakeholder berjenis crowd (tukang rombeng) tidak menjadi sasaran komunikasi mengingat sekalipun kepentingannya cenderung negatif, namun tingkat intensitas interaksi stakeholder ini dengan masyarakat setempat juga sangat sedikit (pengaruhnya kecil). Selain itu, tukang rombeng juga bukan merupakan penduduk lokal Wonokusumo Kidul. 


\section{2) Strategi Komunikasi Stakeholders Bank Sampah Songolikoer}

Pertama, strategi komunikasi stakeholder kepada positive key player stakeholder. Jenis positive key player stakeholder merupakan stakeholder yang memiliki kepentingan yang tinggi terhadap pendirian Bank Sampah. Stakeholder ini terdiri dari: internal anggota kader lingkungan, mitra Bank Sampah yaitu Bank Sampah Induk Surabaya serta masyarakat sebagai calon nasabah Bank Sampah. Strategi komunikasi stakeholder yang diterapkan Bank Sampah Songolikoer terhadap positive key player stakeholder bertujuan untuk meningkatkan komitmen dukungan dari para stakeholders terhadap pendirian Bank Sampah.

Strategi komunikasi stakeholder kepada anggota kader lingkungan. Kepada anggota kader lingkungan dilakukan komunikasi stakeholder dalam bentuk forum diskusi terkait dengan nilai kebutuhan, prospektus, dan mekanisme pendirian Bank Sampah. Dalam forum ini, Bapak Ketua RW bersama salah satu penggagas Bank Sampah menyampaikan persoalan yang ada di wilayah Wonokusumo Kidul yaitu tingkat kepedulian terhadap lingkungan dan sampah sangat rendah. Rendahnya kepedulian masyarakat Wonokusumo Kidul sampai pernah disampaikan oleh Ibu Wali Kota Tri Rismaharini saat mengunjungi Wonokusumo Kidul dan masuk ke YouTube. Oleh karena itu, Bapak Ketua RW menjelaskan pentingnya untuk mendirikan Bank Sampah di wilayah ini agar bisa mengubah mindset masyarakat bahwa Wonokusumo Kidul adalah kampung yang tidak bisa diatur. Selain itu, salah satu penggagas Bank Sampah juga menyampaikan bahwa adanya Bank Sampah tidak hanya memiliki nilai secara lingkungan namun juga dapat menjadi amal jariyah. Selain itu, Ketua RW juga menyampaikan bahwa tidak mewajibkan semua anggota kader lingkungan karena sifatnya hanya menawarkan untuk bersama-sama mendirikan Bank Sampah.

Pada saat forum diskusi dengan anggota kader lingkungan. Anggota kader lingkungan juga diberikan kesempatan untuk menyampaikan aspirasinya terkait dengan pendirian Bank Sampah. Adapun aspirasi yang diperoleh antara lain: (1) harapan adanya Bank Sampah jangan sampai merugikan warga yang selama ini telah mencari sampah; (2) harapannya dapat istikamah menjalankan Bank Sampah, tidak hanya semangat di awal saja namun juga masing-masing anggota bisa konsisten menjalankannya; dan (3) ada anggota yang berharap kesolidan agar tidak terasa bekerja sendiri-sendiri. Aspirasi tersebut diterima oleh Ketua Bank Sampah Songolikoer maupun Bapak Ketua RW. Aspirasi tersebut menjadi landasan program Bank Sampah Songolikoer.

Dari gambaran strategi komunikasi stakeholder di atas, terdapat strategi asertif yang diterapkan dalam bentuk cara-cara yang tidak memaksa/mewajibkan, namun tetap berupaya untuk menyampaikan kepentingan pendirian Bank Sampah sebagai suatu hal yang penting dilaksanakan. Selain itu, juga ada strategi yang bersifat responsif dalam bentuk membuka dialog dan memperhatikan kepentingan dari masingmasing anggota kader lingkungan.

Strategi komunikasi stakeholder kepada masyarakat calon nasabah bank sampah. Strategi komunikasi stakeholder diterapkan 
pada masyarakat Wonokusumo Kidul sebagai calon nasabah Bank Sampah agar masyarakat dapat menyadari nilai penting adanya Bank Sampah, bersedia menjadi nasabah Bank Sampah dan memahami aturan yang berlaku di Bank Sampah. Strategi komunikasinya menggunakan berbagai media yang bersifat komunikasi massa. Antara lain: melalui mengadakan forum sosialisasi Bank Sampah untuk seluruh masyarakat Wonokusumo Kidul, edukasi melalui grup media sosial (WhatsApp dan Facebook). Dalam membangun kesadaran masyarakat Wonokusumo Kidul terhadap Bank Sampah dengan menunjukkan manfaat Bank Sampah baik secara ekonomis, lingkungan maupun spiritual. Manfaat ekonomis adalah yang paling dominan disampaikan kepada masyarakat calon nasabah, sebab masyarakat tergolong menengah ke bawah yang kepentingan utamanya adalah mendapatkan pemasukan. Manfaat ekonomis yang disampaikan meliputi: (1) prospektus banyaknya jumlah sampah yang terdapat di wilayah Wonokusumo Kidul karena dekat dengan TPS (tempat pembuangan sampah); (2) Banyak jenis sampah rumah tangga/seharihari yang selama ini tidak dapat dijual pada tukang rombeng, dapat dijual ke Bank Sampah untuk mendapatkan tambahan pemasukan; misalnya: bekas minyak habis pakai (jelantah), sepatu dan sandal yang rusak, kertas jenis dupleks. (3) Dengan menabung sampah, masyarakat dapat memanfaatkan uang tabungan untuk tambahan kebutuhan hari raya yang biasanya cukup besar. Uang tabungan sampah juga masih memungkinkan diambil sewaktu-waktu apabila ada kebutuhan yang penting dan mendesak.
Manfaat secara lingkungan juga disampaikan dalam pelaksanaan strategi komunikasi stakeholder kepada masyarakat. Manfaat secara lingkungan meliputi: dengan menabung sampah, maka akan menghindarkan masyarakat dari penyakit serta mengurangi pemborosan sumber daya alam. Selain itu, dengan lingkungan yang bersih dapat menjadi potensi daya tarik wisata kedepannya.

Sedangkan, manfaat spiritual yang disampaikan meliputi: mengedukasi masyarakat bahwa kegiatan yang dilakukan oleh Bank Sampah berorientasi Iillahi ta'ala, bukan berorientasi profit. Harapannya dengan adanya Bank Sampah dapat mengubah masyarakat Wonokusumo Kidul menjadi lebih peduli terhadap kebersihan lingkungan. Masyarakat yang sebagian besar merupakan masyarakat Islam Nadlhatul Ulama, sangat memperhatikan nilai-nilai pahala keakhiratan. Sehingga dalam menyampaikan nilai penting pendirian Bank Sampah juga dijelaskan aspek pahala dari amal saleh menabung sampah. Amal jariah yang besar dari menabung sampah dikarenakan, persoalan sampah khususnya sampah plastik adalah masalah yang besar bagi lingkungan. Sampah plastik menyumbangkan pencemaran lingkungan terbesar di bumi, baik pada tanah maupun laut. Serta sifatnya sangat sulit terurai. Yang mana jika menabung sampah maka generasi kedepannya juga akan dapat menikmati kondisi alam yang tidak tercemar. Hal ini sejalan dengan semangat Islam rahmatan li al-alamin.

Selain disampaikan tentang manfaat pendirian Bank Sampah, juga dijelaskan pula tentang aturan-aturan yang berlaku di Bank Sampah, yang mana di dalamnya terdapat 
hak dan kewajiban nasabah dan pengurus Bank Sampah.

Komunikasi stakeholder kepada masyarakat pertama kali dilaksanakan dalam acara tasyakuran satu tahun kader lingkungan. Di dalamnya ada kegiatan ramah tamah berupa makan-makan, pembacaan ayat suci AlQur'an dan terjemah, mengenalkan program pendirian Bank Sampah Songolikoer dan prospektusnya, tanya jawab, dan menampung aspirasi masyarakat dan ditutup dengan doa. Dengan adanya strategi komunikasi stakeholder di atas, akhirnya banyak yang tahu tentang rencana pendirian Bank Sampah. Masyarakat kemudian mendukung dan banyak yang mendaftar sebagai nasabah Bank Sampah Songolikoer.

Dari pemaparan di atas, itu strategi komunikasi yang diterapkan bersifat responsif untuk mengakomodir kepentingan-kepentingan masyarakat dengan lebih menekankan kepada manfaatmanfaat ekonomis yang dapat diperoleh dengan pendirian Bank Sampah. Selain itu cara yang dilakukan bersifat diskusi, tidak memaksa, cenderung santai dan memungkinkan masyarakat menyampaikan aspirasinya. Namun, juga terdapat aspek strategi komunikasi stakeholder yang bersifat asertif, khususnya dalam hal kepentingan utama pendirian Bank Sampah yaitu dengan menarik masyarakat untuk menjadi nasabah Bank Sampah, serta bersedia mengikuti aturan-aturan yang berlaku dalam Bank Sampah.

Strategi komunikasi stakeholder kepada mitra BSIS (Bank Sampah Induk Surabaya). Strategi komunikasi stakeholder Bank Sampah Songolikoer bertujuan membangun kerja sama yang baik dengan Bank Sampah
Induk Surabaya sebagai mitra kerja sama. Kerja sama dengan Bank Sampah Induk Surabaya adalah untuk menampung hasil pengumpulan sampah serta BSIS dapat memberikan pembinaan/pelatihan kemampuan untuk pengembangan Bank Sampah.

Strategi komunikasi stakeholder dilakukan melalui kunjungan langsung ke kantor Bank Sampah Induk Surabaya, negosiasi kontrak kerja sama antara Bank Sampah Songolikoer dan Bank Sampah Induk Surabaya. Dalam proses negosiasi kontrak, pihak Bank Sampah Songolikoer diwakili oleh Ketua Bank Sampah menyampaikan keinginannya antara lain: (1) agar Bank Sampah Induk dapat mengambil sampah secara rutin dengan waktu kesepakatan yang jelas; (2) BSIS dapat membantu sosialisasi ke masyarakat tentang nilai penting pendirian Bank Sampah; (3) BSIS dapat memberikan bantuan pembinaan kapasitas pengurus Bank Sampah Songolikoer.

Sedangkan Bank Sampah Induk juga menyampaikan kepentingan-kepentingannya meliputi: (1) Bank Sampah Induk Surabaya meminta dimasukkan dalam struktur pembina pada struktur organisasi Bank Sampah Songolikoer; (2) jadwal hari pengambilan sampah yang dilakukan oleh Bank Sampah Induk pada Bank Sampah Songolikoer mempertimbangkan kapasitas Bank Sampah Induk Surabaya. Termasuk ketentuan minimal sampah yang dapat diangkut; (3) harga sampah, ditetapkan mengikuti ketentuan yang dibuat oleh Bank Sampah Induk; (4) terdapat batasan waktu minimal kerja sama.

Dalam negosiasi tersebut kedua belah pihak sepakat mengakomodasi kepentingan 
masing-masing pihak. Hal tersebut tertuang dalam kontrak kesepakatan yang dibuat. Dari gambaran strategi komunikasi stakeholder di atas menunjukkan bahwa dalam berkomunikasi dengan mitra kerja sama, Bank Sampah Songolikoer cenderung menggunakan strategi komunikasi asertif dan responsif. Hal itu dikarenakan kedua lembaga memiliki kepentingan yang tinggi yang harus terakomodasi melalui strategi komunikasi yang dilaksanakan. Sedangkan, cara-cara yang bersifat tidak memaksa, dialog kepentingan kedua belah pihak dan menuangkan kesepakatan dalam kontrak tertulis dapat menjalin kerja sama yang harmonis di antara kedua belah pihak baik jangka pendek maupun jangka panjangnya.

Kedua, strategi komunikasi stakeholder kepada negative key player dan subject stakeholder. Masyarakat Wonokusumo Kidul yang sebelumnya telah berprofesi sebagai pengumpul sampah, ada yang merupakan key player stakeholder dan subject stakeholder. Mereka ini memiliki kepentingan yang bersifat negatif dan kuat terhadap pendirian Bank Sampah. Upaya yang dilakukan kepada kedua jenis stakeholder ini secara umum dengan mengajak dialog terkait prospektus bergabung di Bank Sampah serta menunjukkan bahwa Bank Sampah bukanlah pesaing mereka dan tidak akan merugikan kepentingan masyarakat yang telah berprofesi mengumpulkan sampah.

Pengurus Bank Sampah menyampaikan beberapa program yang mengakomodasi kepentingan masyarakat yang sebelumnya telah mengumpulkan sampah sebelum berdirinya Bank Sampah. Pertama, menunjukkan adanya fasilitas pembelian sampah dengan harga sesuai dengan harga biasanya ketika menjual pada rombeng/pengepul besar, bahkan ada yang lebih tinggi, hal ini akan dimasukkan sebagai bagian dari program sosial Bank Sampah Songolikoer. Kedua, membangun kesepakatan bahwa pengurus atau nasabah Bank Sampah tidak akan mengumpulkan sampah pada wilayah-wilayah yang biasanya dikerjakan oleh masyarakat yang berprofesi mengumpulkan sampah, seperti: wilayah perumahan. Komunikasi yang dilakukan bersifat dialog personal. Strategi komunikasi stakeholder tersebut dilaksanakan oleh Ketua RW dan masing-masing pengurus Bank Sampah kepada keluarganya.

Khusus untuk jenis negatif keyplayer stakeholder (tokoh masyarakat), strategi komunikasi stakeholder yang dilakukan tidak hanya berupa dialog menunjukkan prospektus dan program yang mengakomodasi kepentingan masyarakat yang sebelumnya telah mengumpulkan sampah. Namun, juga dengan cara melibatkan beliau dalam kegiatan-kegiatan Bank Sampah yang mana di dalam program tersebut keyplayer stakeholder mendapatkan keuntungan ekonomi tambahan, misalnya: dalam kegiatan peresmian Bank Sampah.

Dari pemaparan di atas, menunjukkan strategi komunikasi yang digunakan adalah responsif artinya: tetap mengutamakan kepentingan dari jenis stakeholder ini dengan mengakomodasi kepentingan mereka dalam program pendirian Bank Sampah, komunikasi yang dilakukan bersifat dialogis dan menerima masukan-masukan kepentingan mereka. Namun, dikombinasikan dengan strategi asertif yaitu dengan komunikasi persuasif yang arahnya agar mereka mendukung kepentingan 
lembaga terkait dengan kelancaran proses pendirian Bank Sampah Songolikoer.

Ketiga, strategi komunikasi stakeholder kepada positive context setter stakeholder. Strategi komunikasi stakeholder kepada Ketua RT. Ketua RT-02 merupakan salah satu stakeholder berjenis Context Setter yang mana secara kepentingan rendah namun pengaruhnya kuat dalam hal memberikan perizinan pendirian Bank Sampah. Mengingat kepentingan ketua RT-02 yang tidak terlalu kuat terkait program pendirian Bank Sampah, maka strategi komunikasi yang diterapkan bersifat asertif yaitu lebih menekankan pada kepentingan pengurus Bank Sampah untuk dapat mendirikan Bank Sampah di wilayah Wonokusumo Kidul. Namun, tetap ada strategi responsif dalam bentuk menyampaikan dengan bil-hikmah, tidak memaksakan pendirian Bank Sampah, mendengar, dan membuka dialog terkait pandangan Ketua RT terkait dengan pendirian Bank Sampah. Meski strategi yang bersifat responsif tidak dominan, karena Ketua RT-02 cenderung mendukung saja program-program yang memang memiliki nilai kemaslahatan di masyarakat.

Penerapan strategi komunikasi stakeholder kepada Ketua RT dilakukan oleh Ketua RW. Hal yang disampaikan tentang ide pendirian Bank Sampah di kampung Wonokusumo Kidul. Ketua RW menunjukkan permasalahan terkait kebersihan di kampung Wonokusumo Kidul, nilai penting pendirian Bank Sampah, rencana gambaran pendirian Bank Sampah Songolikoer serta gambaran semangat remaja kader untuk mendirikan Bank Sampah. Dari penjelasan tersebut, beliau sangat senang dengan adanya keaktifan daripada remaja masjid dan warga yang tergabung dalam kader lingkungan. Ketua RT menyetujui rencana pendirian Bank Sampah, memberikan izin pendiriannya, sekaligus bersedia hadir dalam peresmian pendirian Bank Sampah pada tanggal 18 Januari 2019, dan beliau menyanggupi untuk hadir.

Strategi komunikasi stakeholder kepada sebagian anggota remaja masjid dan kader posyandu yang tidak tergabung dalam kegiatan Kader Lingkungan ataupun Bank Sampah. Anggota Remaja Masjid Ar-Rahman dan kader Posyandu Wonokusumo Kidul yang tidak tergabung dalam kegiatan Bank Sampah merupakan jenis context setter stakeholder. Kepentingan mereka tidak terlalu kuat terhadap pendirian Bank Sampah namun juga memiliki potensi tantangan konflik kepentingan. Konfik tersebut dapat terjadi antara anggota remaja masjid yang menjadi pengurus Bank Sampah dan yang bukan pengurus, yaitu berupa iri hati karena tidak semua anggota remaja masjid membantu di Bank Sampah. Selain itu adanya potensi bertabrakan jadwal antar dua kegiatan. Sehingga, sekalipun adanya kesejalanan arah kegiatan dalam memberikan manfaat di masyarakat Wonokusumo Kidul namun tetap harus ada upaya komunikasi untuk mencegah terjadinya konflik-konflik kepentingan.

Strategi komunikasi stakeholder yang dilakukan dengan diskusi dan membuat kesepakatan bersama untuk mengakomodasi kepentingan kedua organisasi. Pengurus Bank Sampah Songolikoer menyampaikan pada anggota remaja masjid atau kader Posyandu bahwa kegiatan yang akan dilaksanakan Bank Sampah diusahakan tidak bertabrakan dengan kegiatan yang lain. Khususnya jika ada pengajian, kegiatan posyandu, PHBI 
(peringatan hari besar Islam) maka jam operasional Bank Sampah akan menyesuaikan. Selain itu, jika ada kegiatan yang lebih utama misalkan kegiatan pelatihan persiapan PHBI maka tidak harus membantu kegiatan Bank Sampah Songolikoer, sehingga peran/tugasnya akan digantikan oleh pengurus yang selainnya. Hal lain yang dilakukan adalah dengan memberikan kesadaran pada anggota Bank Sampah bahwa jangan sampai iri hati dengan teman-teman remaja masjid yang lain yang tidak membantu Bank Sampah. Mengingat, ada perbedaan lingkup organisasi Remaja Masjid dan Bank Sampah.

Strategi komunikasi stakeholder yang dilakukan bersifat kombinasi antara strategi asertif dan responsif. Strategi asertif ditunjukkan dari adanya upaya menunjukkan nilai penting berdirinya Bank Sampah di kampung Wonokusumo Kidul. Strategi komunikasi responsif, yang cenderung mengakomodasi kepentingan dari remaja masjid dan kader Posyandu juga digunakan untuk mencegah konflik.

Strategi komunikasi stakeholder kepada pemerintah lokal (Ketua Camat dan Lurah). Dalam rangka membangun komunikasi dengan lurah dan camat setempat adalah melalui upaya mengundang Bapak Camat dan Lurah pada kegiatan pendirian Bank Sampah. Namun, Bapak Camat dan Lurah saat pendirian Bank Sampah tidak dapat hadir sehingga tidak diketahui responnya. Namun, sejauh ini komunikasi stakeholder telah dilaksanakan berupa mengajukan izin resmi pengadaan Bank Sampah di wilayah Wonokusumo Kidul. Saat ini Bank Sampah telah memiliki izin domisili dari aparat lokal setempat dan SK dari Dinas Lingkungan Hidup Kota Surabaya.

\section{Analisis Strategi Komunikasi Stakeholders Bank Sampah Songolikoer}

Dari pemaparan di atas dapat diketahui berbagai strategi komunikasi stakeholder yang dilaksanakan oleh Bank Sampah Songolikoer. Jika ditinjau dari teori strategi komunikasi stakeholder, strategi yang diterapkan oleh pengurus Bank Sampah Songolikoer bersifat kombinasi antara jenis strategi komunikasi asertif dan responsif. Artinya Pengurus Bank Sampah Songolikoer dalam melaksanakan strategi komunikasi stakeholder berupaya mempertahankan kepentingan organisasi untuk dapat mendirikan Bank Sampah di wilayah Wonokusumo Kidul. Namun, juga memberi perhatian terhadap kepentingan stakeholder luarnya. Sehingga, kepentingan yang dimiliki oleh subject stakeholder, keyplayer stakeholder, maupun context setter stakeholders dapat terakomodasi dengan baik serta tidak ada yang merasa dinomorduakan. Meskipun secara porsi strategi komunikasi stakeholder yang dilaksanakan lebih banyak kepada stakeholder yang memiliki kepentingan tinggi terhadap pendirian Bank Sampah.

Strategi asertif ditunjukkan dari cara-cara yang digunakan bersifat tidak memaksa. Misalnya dengan menunjukkan nilai penting atau kemanfaatan berdirinya Bank Sampah baik secara ekonomi, ekologis, maupun spiritual. Serta menghindari cara-cara yang mengejek atau menyinggung stakeholder lainnya. Sedangkan strategi yang bersifat responsif dilaksanakan dalam bentuk usaha mempertimbangkan kepentingan masingmasing jenis stakeholder dalam program Bank Sampah, melakukan dialog baik secara personal maupun kelompok untuk 
menyamakan kepentingan dari berbagai pihak, serta mendorong pula masing-masing pihak agar mau menyesuaikan kepentingannya.

Dengan strategi komunikasi yang bersifat asertif dikombinasikan dengan responsif, hasilnya seluruh stakeholder yang ada di masyarakat Wonokusumo Kidul dapat mendukung pendirian Bank Sampah Songolikoer. Bahkan ada salah seorang tokoh masyarakat yang awalnya menolak pendirian Bank Sampah justru saat ini menjadi nasabah Bank Sampah. Hal ini sejalan dengan teori yang dikemukakan oleh Ilyas Yasin yang mana apabila strategi komunikasi stakeholder responsif dan asertif dilaksanakan dapat mengurangi konflikkonflik kepentingan yang memungkinkan terjadi antara stakeholder-stakeholder yang ada.

Adapun pertimbangan menggunakan strategi komunikasi stakeholder yang bersifat asertif dan responsif dikarenakan kepentingan pendirian Bank Sampah merupakan sesuatu yang sudah dikaji dari awal dan sangat dibutuhkan oleh masyarakat Wonokusumo Kidul. Sehingga, kepentingan tersebut tidak dapat dihilangkan atau digantikan dengan kepentingan yang selainnya. Sedangkan, perhatian terhadap kepentingan stakeholder luar, dikarenakan kepentingan dari stakeholder luar tersebut juga merupakan kebutuhan utama bagi masing-masing stakeholder sasaran. Misalnya: 1) bagi masyarakat yang sebelumnya berprofesi sebagai pengepul sampah, sampah merupakan sumber penghasilan utama untuk menghidupi keluarga. Oleh karena itu, tentunya tidak bisa serta merta dapat memaksa stakeholder ini untuk mendukung
Bank Sampah tanpa mengakomodasi kepentingannya; 2) bagi stakeholder kelompok remaja masjid dan kader Posyandu, anggota/SDM mereka adalah juga bagian SDM Bank Sampah, sehingga mereka memiliki kebutuhan untuk menggunakan SDM tersebut dalam menjalankan programprogram organisasinya. Kepentingan kelompok ini harus diperhatikan agar masing-masing organisasi juga tetap dapat sukses menjalankan programnya dan tidak terjadi konflik-konflik kepentingan yang berarti. Sehingga, tidak mungkin sematamata hanya mementingkan kepentingan Bank Sampah Songolikoer. Dalam konteks yang demikian cara-cara yang bersifat tidak memaksa dan tidak menomorduakan kepentingan dari masing-masing stakeholder menjadi relevan diterapkan.

Strategi komunikasi yang bersifat agresif yang bersifat memaksa dan menomorduakan kepentingan stakeholder di luar organisasi tidak diterapkan. Hal itu mengingat dalam kegiatan pemberdayaan masyarakat Islam melalui Bank Sampah, harapannya masing-masing stakeholder dapat mendukung kegiatan Bank Sampah tanpa ada paksaan sehingga lahir partisipasi dan dukungan masyarakat yang harmonis dan berkelanjutan. Selain itu seluruh stakeholder diharapkan dapat memiliki kesadaran terhadap tujuan dan manfaat pendirian Bank Sampah di wilayah Wonokusumo Kidul. Bank Sampah Songolikoer memiliki komitmen agar adanya Bank Sampah dapat memberikan manfaat bagi berbagai stakeholder dan tidak mengakibatkan terjadinya konflik-konflik kepentingan di masyarakat Wonokusumo Kidul. 
Strategi komunikasi stakeholder yang dilaksanakan oleh Bank Sampah Songolikoer mempertimbangkan berbagai aspek, khususnya pada karakteristik stakeholder dan tujuan (kepentingan) organisasi yang terdapat dalam program pendirian Bank Sampah. Aspek karakteristik stakeholder yang dipertimbangkan meliputi: jenis kepentingan (negatif/positif terhadap tujuan organisasi), tingkat pengaruh stakeholder kepada masyarakat dan tingkat kepentingannya.

Teknis pelaksanaan strategi komunikasi stakeholder juga menyesuaikan ketersediaan komunikator dan pesan inti yang ingin disampaikan kepada masingmasing stakeholder. Pesan-pesan dalam strategi komunikasi stakeholder yang dilakukan oleh Bank Sampah Songolikoer berpijak pada karakteristik kepentingan masing-masing stakeholder maupun nilainilai yang dimiliki oleh organisasi Bank Sampah Songolikoer. Nilai-nilai tersebut meliputi manfaat ekonomis, manfaat secara ekologis/lingkungan dan manfaat spiritual dalam pendirian Bank Sampah. Hal itu dikarenakan situasi sosial masyarakat yang juga kecenderungan memiliki nilai-nilai Islam, hidupnya kegiatan-kegiatan sosial keagamaan seperti remaja masjid, pengajian, dan lain sebagainya yang cukup mewarnai masyarakat.

\section{Kesimpulan}

Dari studi yang telah dilaksanakan, dapat disimpulkan bahwa dalam rangka pendirian Bank Sampah Songolikoer memiliki beberapa stakeholder yang terkait dengan kepentingan pendirian Bank Sampah antara lain: (1) masyarakat yang selama ini sudah berprofesi sebagai pengepul sampah; (2) tokoh masyarakat sekitar baik di tingkat RT, RW, kelurahan, maupun kecamatan; (3) stakeholder internal yaitu anggota organisasi kader lingkungan sendiri; (4) serta ada kelompok masyarakat yang SDM-nya terkait dengan Bank Sampah, seperti: remaja masjid dan kader Posyandu; (5) mitra organisasi Bank Sampah yaitu Bank Sampah Induk Surabaya; dan (6) tukang rombeng. Masingmasing stakeholder dapat diklasifikasi sesuai dengan jenis kepentingan, tingkat kepentingan, dan pengaruhnya terhadap keberadaan Bank Sampah Songolikoer.

Strategi komunikasi stakeholder memiliki sasaran komunikan yaitu keyplayer, context setter, dan subject stakeholder. Sedangkan stakeholder yang bersifat crowd tidak dilakukan komunikasi stakeholder mengingat pengaruhnya yang kecil dan kepentingannya juga kecil. Strategi komunikasi yang dilakukan merupakan kombinasi antara strategi komunikasi stakeholder yang bersifat responsif dan asertif. Pola strategi komunikasi stakeholder yang bersifat kombinasi antara strategi responsif dan asertif sangat cocok dengan karakter kegiatan pengembangan masyarakat, yang tidak bisa hanya mempertimbangkan kepentingan salah satu pihak saja. Melainkan harus mengombinasikan antara kepentingan lembaga/subjek pembangun, namun juga tetap memberi perhatian pada masingmasing stakeholder. Cara-cara strategi asertif dan responsif yang cenderung bersifat tidak memaksa, membuka dialog kepentingan di antara kedua belah pihak, serta adanya penyesuaian kepentingankepentingan yang dilakukan oleh masingmasing stakeholder dapat menciptakan hubungan yang harmonis, berkurangnya konflik-konflik dalam kegiatan 
pengembangan masyarakat sekaligus tetap memastikan tercapainya tujuan komunikasi yang diharapkan.

Hasil studi ini harapannya dapat menjadi inspirasi bagi organisasi dakwah atau lembaga sosial kemasyarakatan yang hendak mengembangkan strategi komunikasi stakeholder yang menunjang keberhasilan program pemberdayaan masyarakat Islam yang sedang dijalankan. Subjek pemberdayaan masyarakat perlu melakukan identifikasi terhadap karakteristik stakeholder yang melingkupi, menentukan tujuan komunikasi stakeholder yang diharapkan, serta menetapkan jenis strategi komunikasi stakeholder yang relevan dengan situasi organisasinya.

\section{Bibliografi}

Adi, Isbandi Rukmianto. Intervensi Komunitas \& Pengembangan Masyarakat Sebagai Upaya Pemberdayaan Masyarakat. Jakarta: PT. Raja Grafindo Persada, 2013.

Badan Diklat DIY. Membangun Tim Efektif Bahan Ajar Diklat Kepemimpinan Aparatur Pemerintah Tingkat III. Jakarta, Lembaga Administrasi Negara Republik Indonesia. Yogyakarta: Badan Diklat DIY, 2013. http://diklat.jogjaprov.go.id.

Communication Management \& Stakeholder Engagement, Delivering Successful Change' Version 3.1, Section E - Communication Management \& Stakeholder Engagement. Leeds City Council, Tt. https://leedschildcare.proceduresonline.com/pdfs/com_man_stake_enga.pdf

Faizal. "Dakwah Bil Hal Dalam Perspektif Al-Qur’an." Jurnal Alummah, Vol. 8 No.2 (2014): 255267.

FRA Stakeholder Communication Framework 2011-2013. FRA European Union Agency For Fundamental Right, 2011. 2.

Jeffery, Neil. Stakeholder Engagement: A Road Map to Meaningful Engagement, Doughty Centre. Cranfield School of Management, 2009. http://hdl.handle.net/1826/3801

Kartikawangi, Dorien. "Kolase Komunikasi di Indonesia (Komunikasi Akomodasi dan Konvergensi Simbolis Dalam Interelasi Pemangku Kepentingan)." ASPIKOM 2017. 3-20.

Krisyantono, Rachmat. Teknik Praktis Riset Komunikasi: Disertai Contoh Praktis Riset Media, Public Relation, Advertising, Komunikasi Organisasi, Komunikasi Pemasaran. Jakarta: Kencana, 2010.

Lestari, Dwi dan Mohammad Muktiali. "Peran Pemangku Kepentingan Dalam Pengembangan Klaster Enceng Gondok di Kecamatan Banyubiru." Jurnal Wilayah dan Lingkungan, Vol. 5 No. 3, (2017): 141-155. http://dx.doi.org/10.14710/jwl.5.3.

Liliweri, Alo. Komunikasi: Serba Ada Serba Makna. Jakarta: Kencana, 2011.

Machendrawaty, Nanih dan Agus Ahmad Safei. Pengembangan Masyarakat Islam. Bandung: PT Remaja Rosdakarya, 2001.

Muzani. "Strategi Peningkatan Peran Stakeholder Dalam Pengelolaan Mangove di Kabupaten Tanggerang." SPATIAL Wahana Komunikasi dan Informasi Geografi, Vol.12 No.2 (2014): 21-27.

Mudana, IW. Sosiologi Antropologi Pembangunan. Yogyakarta: Graha IImu, 2015. 
Oestreicher, Klaus. Strategic Communication and the Stakeholder Concept: Merging Marketing Communication and PR. United Kingdom: Henwick Grove, Worcester WR2 6AJ, 2009.

Prastyanti, Shinta. "Komunikasi, Partisipasi dan Konflik Dalam Pemberdayaan Masyarakat." Jurnal Acta Diurna, Vol. 14 No. 1. (2018).

Rif`ati, Eva Faza. "Strategi Mengelola Program Organisasi Dengan Dukungan Seluruh Stakeholder Terkait Dengan Pendekatan Net Mapping Pada Penyusunan Proyek Perubahan Dalam Diklat PIM IV Pola Baru." Forum Manajemen, Vol. 06. No. 02. 10-20.

SPARC. Creating a Stakeholder Communications Plan. New Zealand: SPARC Ihi AOTEAROA, 2006. www.sparc.org.nz.

Stakeholder Engagement Handbook. Paris: Biodiversa, 2014.

Sugiyono. Metode Penelitian Kuantitatif Kualitatif Dan R\&D. Bandung: Alfabeta, 2015.

Water Affairs Republic Of Africa. Stakeholder Communication Strategy to Support the CMAs Establishment Project. South Africa: 2012. 